\title{
Pelembagaan Prinsip Dasar Demokrasi dalam Legislasi Peraturan Daerah di Jawa Timur ${ }^{1}$
}

\author{
Anis Ibrahim \\ Sekolah Tinggi Ilmu Hukum Jenderal Sudirman \\ Jl. Mahakam No. 7 Lumajang- Jatim \\ anisibrahim18@gmail.com
}

\begin{abstract}
This research aims at disclosing empirically legislation practices of regional regulations (Perda) which are analyzed based on the basic principles of democracy. The problems in this research are formulated as follows: (1) Why does the legislation of Regional Regulations in East Java tend to be conducted in elitist way? (2) What factors do obstruct the institutionalization of the basic principles of democracy in the legislation of Regional Regulations in East Java? And, (3) How is the future conceptualization of legislation of Regional Regulations in democracy perspective? To answer the questions, this research uses socio-legal research approach. The result of the research shows that: first, (a) there is a reluctance of the regional elites to disseminate and give room to the community to continually participate in the legislation of Regional Regulations, (b) the process is time-consuming and circuitous, (c) the discussion in Raperda (Regional Regulations meeting) is not focused, (d) lack of budget for the legislation of Regional Regulations activities, (e) not all people understand the matters regulated in Raperda, and (f) regional elites consider that Raperda has already been discussed thoroughly between DPRD (Regional House of Representative) and Regional Government. Second, there are 5 (five) factors that impede the institutionalization of basic principles of democracy in the research area, namely: (a) legal substantial factor,(b) legal structural factor, (c) legal cultural factor, (d) time factor, and (e) budget factor. Third, elite expectation must meet and be harmonious with public expectation.
\end{abstract}

Key words : Institutionalization, democracy, legislation, local regulations, socio-legal-research.

\begin{abstract}
Abstrak
Penelitian ini bertujuan untuk mengungkap secara empirik praktik legislasi peraturan daerah (Perda) yang dianalisis berdasarkan prinsip dasar demokrasi. Masalah dalam penelitian ini dirumuskan sebagai berikut: (1) Mengapa legislasi Peraturan Daerah di Jawa Timur cenderung dilakukan secara elitis? (2) Faktor-faktor apa saja yang menghambat pelembagaan prinsip dasar demokrasi dalam legislasi Peraturan Daerah di Jawa Timur? Dan (3) Bagaimana konseptualisasi legislasi Peraturan Daerah ke depan dalam perspektif demokrasi? Untuk mencapai hal tersebut, maka penelitian ini menggunakan pendekatan socio-legal research. Hasil penelitian menunjukkan bahwa: pertama, (a) adanya keengganan elite daerah untuk menyebarluaskan dan memberi ruang kepada masyarakat untuk secara kontinyu berpartisipasi dalam legislasi Perda, (b) prosesnya akan lama dan berlarut-larut, (c) pembahasan Raperda tidak fokus, (d) minimnya anggaran dalam kegiatan legislasi Perda, (e) tidak semua masyarakat paham materi yang diatur Raperda, ( $f$ ) elite daerah menganggap bahwa Raperda sudah memperoleh pembahasan secara seksama antara DPRD dan Pemerintah Daerah. Kedua, ada 5 (lima) faktor yang menghambat pelembagaan prinsip dasar demokrasi di lokasi penelitian yaitu: (a) faktor substansi hukum,(b) faktor struktur hukum, (c) faktor kultur hukum, (d) faktor waktu, dan (e) faktor anggaran. Ketiga, kehendak elite harus dipertemukan dan diharmonisasikan dengan kehendak umum rakyat.
\end{abstract}

Kata kunci : Pelembagaan, demokrasi, legislasi, peraturan daerah, socio-legal-research.

\footnotetext{
${ }^{1}$ Hasil Penelitian yang didanai oleh Ditlitabmas Dirjen Dikti
} 


\section{Pendahuluan}

Sejak era demokratisasi dan otonomi daerah yang luas diimplementasikan, eksistensi peraturan daerah (Perda) merupakan salah satu isu sentral dan menjadi kontroversi yang hingga kini belum berakhir. Telah berkali-kali Pemerintah Pusat mempublikasikan adanya Perda yang dianggap tidak mampu mewadahi kepentingan nasional, konteks sosial setempat, bertentangan dengan peraturan perundang-undangan yang lebih tinggi dan kepentingan umum, serta yang menurut banyak kalangan dinilai tidak aspiratif baik dari dimensi publik mau pun dunia usaha, sehingga direkomendasikan untuk dibatalkan dan/atau direvisi. ${ }^{2}$ Perda demikian ini kemudian populer dengan sebutan "Perda bermasalah" atau "Perda tidak aspiratif".

Barang tentu munculnya Perda tidak aspiratif tersebut tidak tiba-tiba. Ia muncul setelah melalui legislasi ${ }^{3}$ yang dilakukan oleh elite daerah, yakni pemerintah daerah dan DPRD, yang secara legal memiliki kewenangan untuk itu. Dalam berbagai penelitian menyimpulkan tanda-tanda munculnya proses demokrasi yang elitis setelah terpilihnya elite daerah melalui Pemilu yang demokratis pasca Soeharto. ${ }^{4}$ Dalam legislasi Perda pun tidak lepas dari tengara demikian, yakni legislasi Perda cenderung elitis. Jika hal ini yang terjadi, jelas mencederai dan mendistorsi makna dari demokrasi sebagai government by the people. ${ }^{5}$

Terkait hal ini Steven Vago menyatakan bahwa: "Lawmaking is a complex and continuous process, and it exists as resp onse to a number of social influences that operate in society. The forces that influence lawmaking cannot always be precisely determined, measured, or evaluated". Menurutnya, paling tidak ada tiga hal yang mempengaruhi legislasi, yaitu: interest groups, public opinion, dan social science. ${ }^{6}$ Oleh karenanya, William J.

\footnotetext{
2 "Baru 973 Perda Bermasalah yang Dibatalkan", Kompas, 16 Juli 2008.

${ }^{3}$ Legislasi adalah suatu proses pembuatan hukum dalam rangka melahirkan hukum positif. Lihat Al. Andang L. Binawan, "Merunut Logika Legislasi”, artikel dalam Jentera Jurnal Hukum. Edisi 10 - Tahun III, Oktober 2005, hlm. 9; Satjipto Rahardjo, Sosiologi Hukum, Perkembangan, Metode, dan Pilihan Masalah, Penyunting Khudzaifah Dimyati, Penerbit Muhammadiyah University Press, Surakarta, 2002, hlm. 123.

${ }^{4}$ Robert Endi Jaweng, "Ihwal Perda Bermasalah", artikel dalam Kompas, 24 Maret 2006, hlm. 6. Dalam pengertian yang sejajar, Andi Rahman Alamsyah, "Membangun Oposisi, Memperluas Akuntabiltas, dan Memperkuat Kapasitas: Menuju Pengawasan DPR yang Efektif”, artikel dalam Jentera Jurnal Hukum, Edisi 20 - Tahun V, Januari-April 2010, hlm. 67, dengan mengutip Supriatma dan Ambardi, menyimpulkan bahwa demokrasi di Indonesia pasca-Soeharto menghasilkan politik. kartel, yakni praksis politik di negara demokrasi dimana kekuasaan berpusat pada elit bukan pada rakyat.

${ }^{5}$ Ronald Dworkin, “The Moral Reading”, dalam Tom Campbell and Adrienne Stone (Ed.), Law and Democracy, Dartmouth Publishing Company-Ashgate Publishing Limited, Burlington, 2003, hlm. 15.

${ }^{6}$ Steven Vago, Law and Society. Prentice Hall, Upper Saddle River, New Jersey, 1997, hlm. 166-174.
} 
Chambliss dan Robert B. Seidman sampai pada simpulan bahwa "The legislature is, therefore, not mere neutral forum where pluralistic interest groups can bargain out a compromise solution representing their respective power positions". ${ }^{7}$

Legislasi Perda yang elitis berdampak pada produk hukum daerah yang tidak aspiratif tersebut tentu tidak sejalan dengan hukum ${ }^{8}$ yang mendasari legislasi yang di dalamnya telah dirumuskan ketentuan yang mendukung demokratisasi dalam legislasi Perda pada satu sisi, dan pada sisi bersamaan sistem politik dan ketatanegaraan di Indonesia di era otonomi daerah yang seluas-luasnya telah dianggap cukup demokratis pula jika dibanding dengan era Orde Baru yang sentralistrik dan totaliter.

Nampak bahwa desentralisasi dan otonomi daerah sebagai wujud paling nyata dari penerapan demokrasi tampaknya tidak berbanding lurus pada level legislasi Perda yang niscaya demokratis-partisipatoris. ${ }^{9}$ Gerakan Critical Legal Studies telah mengingatkan bahwa legislasi untuk menjadikan hukum positif (in abstracto) selalu merupakan hasil dari proses yang sarat dengan berbagai muatan, nilai, dan kepentingan para aktor, yang di dalamnya niscaya mengandung pemihakan-pemihakan. ${ }^{10}$

Untuk mengetahui dan menganalisis latar belakang penyebab legislasi Perda yang dilakukan secara elitis tersebut maka menjadi penting untuk dilakukan penelitian: Pelembagaan Prinsip Dasar Demokrasi dalam Legislasi Peraturan Daerah (Analisis Proses Pembentukan Peraturan Daerah di Jawa Timur dalam Perspektif Demokrasi). Level demokrasi di tingkat daerah, khususnya dalam konteks legislasi Perda, menjadi penting diteliti dengan maksud untuk menganalisis apakah kedekatan jarak antara elite lokal dengan rakyat di daerahnya dengan prinsip dasar demokrasi seperti prinsip partisipasi publik, prinsip transparansi, prinsip kesetaraan, kontrol rakyat terhadap proses kebijakan yang dibuat elite $^{11}$ - telah terlembagakan dengan baik dalam legislasi Perda.

${ }^{7}$ William J. Chambliss dan Robert B. Seidman, Law, Order and Power, Addison-Wesley Publishing, Inc. Philippines, 1971, hlm. 73 .

${ }^{8}$ Ketentuan hukum tersebut masih bersifat relatif. Lihat Saldi Isra, "Agenda Pembaruan Hukum: Catatan Fungsi Legislasi DPR”, artikel dalam Jentera Jurnal Hukum, Edisi 3-Tahun II, November 2004, hlm. 71-72.

${ }^{9}$ Mengenai teori demokrasi elitis dan demokrasi partisipatoris lihat SP. Varma, Teori Politik Modern, Terjemahan dari Modern Political Theory, Alih Bahasa, Yohanes Kristiarto SL (dkk.), PT RajaGrafindo Persada, Jakarta, 2007, hlm. 210-223.

${ }^{10}$ Ifdhal Kasim, “Mempertimbangkan 'Critical Legal Studies' dalam Kajian Hukum di Indonesia”, artikel dalam Jurnal Wacana, Edisi 6, Tahun II, 2000, hlm. 25. Lihat pula F.X. Adji Samekto, Studi Hukum Kritis, Kritik Terhadap Hukum Modern, Badan Penerbit Universitas Diponegoro, Semarang, 2003, hlm. 68.

${ }^{11}$ M.C. Burkens et al., Beginselen van de Democratische Rechtsstaat. W.E.J. Tjeenk Willink, Zwolle in Samenwerking met het Nederlands Institut voor Sociaal en Economisch Recht, NISER, 1990; P. De Haan et al., Bertuursrecht in Sociale 


\section{Rumusan Masalah}

Dari latar belakang masalah tersebut, maka masalah dalam penelitian ini dirumuskan sebagai berikut: (1) Mengapa legislasi Peraturan Daerah di Jawa Timur cenderung dilakukan secara elitis? (2) Faktor-faktor apa saja yang menghambat pelembagaan prinsip dasar demokrasi dalam legislasi Peraturan Daerah di Jawa Timur? (3) Bagaimana konseptualisasi legislasi Peraturan Daerah ke depan dalam perspektif demokrasi?

\section{Tujuan Penelitian}

Tujuan dari penelitian ini adalah: (1) Untuk mendeskripsikan dan menganalisis legislasi Peraturan Daerah di Jawa Timur yang cenderung dilakukan secara elitis; (2) Untuk mengetahui faktor-faktor yang menghambat pelembagaan prinsip dasar demokrasi dalam legislasi Peraturan Daerah di Jawa Timur; (3) Untuk mengkonseptualisasi legislasi Peraturan Daerah ke depan dalam perspektif demokrasi.

\section{Metode Penelitian}

Penelitian hukum ini ditujukan untuk memperoleh bukti empirik, menjelaskan, dan menganalisis proses pembentukan peraturan daerah (legislasi Perda) yang ditinjau dari perspektif demokrasi, serta berusaha mengajukan konsep demokrasi dalam legislasi Perda ke depan. Pendekatan yang digunakan dalam penelitian ini adalah penelitian yuridis empirik (socio-legal research). Pendekatan yang demikian ini dikarenakan penelitian ini tidak semata-mata mengkaji aspek hukum legislasi Perda secara normatif saja, namun juga mengkajinya dari sisi empirik ketika norma hukum berinteraksi dalam kehidupan sosio-politik di sekitarnya. ${ }^{12}$

\footnotetext{
Rechtsstaat, deel 2 Bertuurshandelingen en waarborgen. Kluwer, Deventer, 1986, hlm. 122; P.W.C. Akkersmans et al. Algemene Begrippen van Staatsrecht, deel I. W.E.J. Tjeenk, Zwolle, 1985, hlm. 161, lihat pada Philipus M. Hadjon, "Keterbukaan Pemerintahan dan Tanggung Gugat Pemerintah”, makalah pada Seminar Hukum Nasional Reformasi Hukum Menuju Terwujudnya Masyarakat Madani (Civil Society), Badan Pembinaan Hukum Nasional, Departemen Kehakiman, Jakarta, 12-15 Oktober 1999, hlm. 4-6. John Ferejohn, Participation and Democracy, Stanford University, 2005, hlm. 10. Marc Bühlmann, Wolfgang Merkel, and Bernhard Wessels The Quality of Democracy: Democracy Barometer for Established Democracies. NCCR Democracy, University of Zurich, Social Science Research Centre Berlin (WZB), 2007, hlm. 13-14.

12 Tom Campbell and Adrienne Stone (Ed.), Law and Democracy, Dartmouth Publishing Company-Ashgate Publishing Limited, Burlington, 2003, hlm. xi.
} 
Sedangkan jenis penelitian hukum ini adalah penelitian kuantitatif-kualitatif dengan level eksplanatif yaitu menjelaskan dan membuktikan kecenderungan berbagai variabel yang diteliti, yang kemudian diteruskan untuk menemukan dan mengajukan konsep demokrasi (konseptualisasi demokrasi) yang niscaya dalam legislasi Perda. Adapun fokus lokasi penelitiannya adalah: Kota Blitar, Kota Probolinggo, Kabupaten Lumajang, dan Kabupaten Tulungagung yang semuanya merupakan Kota dan Kabupaten yang berada di wilayah Propinsi Jawa Timur.

\section{Hasil Penelitian dan Pembahasan}

\section{Berbagai Peraturan Perundang-Undangan yang Mengatur Legislasi Peraturan Daerah}

Ada berbagai peraturan perundang-undangan yang menjadi acuan hukum dalam legislasi Perda di lokasi penelitian, yaitu: 1. UU No. 10 Tahun 2004 tentang Pembentukan Peraturan Perundang-undangan. 2. UU No. 32 Tahun 2004 tentang Pemerintahan Daerah. 3. Peraturan Pemerintah (PP) No. 16 Tahun 2010 tentang Pedoman Penyusunan Peraturan Dewan Perwakilan Daerah tentang Tata Tertib DPRD. 4. Peraturan Menteri Dalam Negeri (Permendagri) Nomor 16 tahun 2006 tentang Prosedur Penyusunan Produk Hukum Daerah. 5. Peraturan Tata Tertib Dewan Perwakilan Rakyat Daerah (Peraturan Tatib DPRD) pada masing-masing daerah otonom: a. Peraturan DPRD Kota Probolinggo No. 01 Tahun 2010 tentang Tata Tertib Dewan Perwakilan Rakyat Daerah Kota Probolinggo; b. Peraturan DPRD Kota Blitar No. 01 Tahun 2010 tentang Tata Tertib Dewan Perwakilan Rakyat Daerah Kota Blitar. c. Keputusan DPRD Kabupaten Lumajang No. 04 Tahun 2010 tentang Peraturan Tata Tertib Dewan Perwakilan Rakyat Daerah Kabupaten Lumajang. d. Peraturan DPRD Kabupaten Tulungagung No. 01 Tahun 2010 tentang Tata Tertib Dewan Perwakilan Rakyat Daerah Kabupaten Tulungagung.

Pada saat penelitian ini dilangsungkan, semua DPRD di lokasi penelitian telah menyesuaikan Peraturan Tatibnya dengan PP Nomor 16 Tahun 2010 tersebut. Meski semua rumusan tata cara pembentukan Perda dalam semua Peraturan Tatib DPRD di lokasi penelitian persis sama dengan yang ada dalam PP No. 16/2010, namun dalam Peraturan Tatib DPRD Kabupaten Lumajang ada tambahan 1 ayat yang menjadikannya agak berbeda dengan Peraturan Tatib DPRD yang lain. 
Pasal 110 ayat (8) Peraturan Tatib DPRD Kabupaten Lumajang merumuskan bahwa Perda yang dibentuk tidak boleh bertentangan dengan kepentingan umum, peraturan perundang-undangan yang lebih tinggi dan peraturan daerah lainnya. Sementara Peraturan Tatib DPRD lainnya tidak mengatur dan merumuskan tentang larangan demikian ini. Ada pun rumusan pasal dan ayat lainnya sama sekali tidak ada perbedaan yakni kesemuanya tampak sebagai turunan dan merupakan copy paste dari PP No. 16 Tahun 2010.

Pada saat penelitian ini dilangsungkan, masing-masing Pemda telah memiliki website. Website Pemerintah Kota (Pemkot) Probolinggo dapat diakses di: http:// probolinggokota.go.id, Website Pemkot Blitar dapat diakses di: http:// www.blitar.go.id, Webiste Pemerintah Kabupaten (Pemkab) Lumajang dapat diakses di: http://www.lumajang.go.id, dan Website Pemkab Tulungagung dapat diakses di: http:/ / www.tulungagung.go.id. Jika ditelusuri, ternyata website tersebut belum digunakan secara maksimal untuk mempublikasikan Raperda.

Semua DPRD di lokasi penelitian telah memiliki alat kelengkapan yang berupa Badan Legislasi Daerah (Balegda). Sesuai dengan Peraturan Tatib DPRD, Balegda inilah yang akan terkait erat dengan masalah legislasi Perda. Tabel 1 berikut menunjukkan nama-nama Ketua Balegda DPRD di lokasi penelitian.

Jumlah Perda yang dibentuk dalam kurun waktu 7 bulan terakhir yaitu dari bulan Januari 2011 hingga bulan Juli 2011 - baik yang sudah disahkan maupun

Tabel 1

Ketua Badan Legislasi Daerah DPRD di Lokasi Penelitian Periode 2009-2014

\begin{tabular}{|c|l|l|}
\hline No. & \multicolumn{1}{|c|}{ DPRD } & \multicolumn{1}{|c|}{ NAMA KETUA BALEGDA } \\
\hline 1 & KOTA PROBOLINGGO & H.M. Yusuf Susanto,SH.,MBA. \\
2 & KOTA BLITAR & Suwoko,ST.,MH. \\
3 & KABUPATEN LUMAJANG & Ahmad Lukman Hakim,SE. \\
4 & KABUPATEN TULUNGAGUNG & Suprapto,SH.,MMA. \\
\hline
\end{tabular}

Sumber: Data Sekunder Tahun 2010 diolah

yang akan dibahas - semuanya adalah 33 Perda/Reperda. Dari semua Perda/ Raperda tersebut Perda yang termasuk dalam rumpun aktivitas usaha yang berdampak pada pungutan terhadap masyarakat menempati urutan paling banyak yaitu 75,76\%. Sedangkan Perda/Raperda dalam rumpun kehidupan sosial maupun Perda dalam rumpun organisasi dan administrasi pemerintahan sama jumlahnya 
yaitu masing-masing 12,12\%.

Secara keseluruhan Perda yang terkait dengan rumpun kehidupan sosial memang lebih sedikit jika dibanding dengan rumpun Perda aktivitas usaha, yaitu

Tabel 2

Komposisi Perda di Lokasi Penelitian Januari-Juli 2011

\begin{tabular}{|c|l|c|c|c|c|c|c|}
\hline No. & \multicolumn{1}{|c|}{ Rumpun PERDA } & $\begin{array}{c}\text { Kota } \\
\text { Probolinggo }\end{array}$ & $\begin{array}{c}\text { Kota } \\
\text { Blitar }\end{array}$ & $\begin{array}{c}\text { Kab. } \\
\text { Lumajang }\end{array}$ & $\begin{array}{c}\text { Kota } \\
\text { Tulungagung }\end{array}$ & Jmlh & $\%$ \\
\hline 1 & Organisasi \& Administrasi & 0 & 0 & 2 & 2 & 4 & 12,12 \\
2 & Pemerintahan & 4 & 7 & 11 & 4 & 25 & 75,76 \\
3 & Aktivitas Usaha & 0 & 2 & 0 & 2 & 4 & 12,12 \\
\hline \multicolumn{2}{|l|}{ Kehidupan Sosial } & 4 & 9 & 13 & 8 & 33 & 100,00 \\
\hline
\end{tabular}

Sumber: Data Sekunder Tahun 2011 diolah

hanya $12,12 \%$. Namun, Pemkot Blitar yang mengajukan Raperda yang akan dibahas pada sidang bulan Agustus 2011 terdapat satu Raperda yang cukup menarik dalam kaitannya dengan demokratisasi dalam pembuatan kebijakan termasuk legislasi Perda yaitu draf Rancangan Peraturan Daerah Kota Blitar tentang Keterbukaan Informasi Publik.

Namun, jauh hari sebelumnya, yaitu pada 2003 Pemkot Probolinggo dan DPRD Kota Probolinggo telah menerbitkan Perda terkait dengan kehidupan sosial yang bersinggungan langsung dengan bidang politik dalam dikaitkan dengan kehidupan demokrasi. Pada 2003 tersebut Perda yang demikian itu tidak dimiliki oleh tiga daerah lokasi penelitian lainnya. Kedua Perda di Kota Probolinggo tersebut adalah: a. Perda No. 5 Tahun 2003 tentang Partisipasi Masyarakat; b. Perda No. 6 Tahun 2003 tentang Kebebasan Memperoleh Informasi.

Kedua Perda itu cukup progresif, sebab ketika Perda itu dibentuk pada 2003, pada saat itu UU tentang Keterbukaan Informasi Publik (Nomor 14 Tahun 2008) yang menjadi rujukan terkait masalah tersebut belum ada. Dengan diterbitkannya kedua Perda tersebut, pada 2003 Pemerintah Kota Probolinggo memperoleh penghargaan Region in a Leading Commitment on Public Participation (Partisipasi Publik) dari Jawa Pos Institute Pro Otonomi Award (JPIP).

Acuan tentang Raperda yang akan dibahas pada 2011 di lokasi penelitian ada yang didasarkan pada Prolegda dan ada yang belum didasarkan pada Prolegda. Dari empat lokasi penelitian, pada 2011 hanya Kabupaten Lumajang yang belum membuat Prolegda. Sedangkan tiga daerah lainnya, yaitu Kabupaten Tulungagung, 
Kota Blitar dan Kota Probolinggo masing-masing telah memiliki Prolegda.

\section{Tabel 3}

Eksistensi Prolegda di Lokasi Penelitian 2011

\begin{tabular}{|c|c|c|}
\hline No. & DPRD & BINGKAI HUKUM \\
\hline 1 & Kota Probolinggo & $\begin{array}{l}\text { Peraturan Walikota Probolinggo No. } 8 \text { Tahun } 2011 \text { tentang Pro- } \\
\text { gram Legislasi Daerah Kota Pronolinggo Tahun } 2011\end{array}$ \\
\hline 2 & Kota Blitar & $\begin{array}{l}\text { Peraturan Walikota Blitar No. } 25 \text { Tahun } 2011 \text { tentang Program } \\
\text { Legislasi Daerah Kota Blitar Tahun } 2011\end{array}$ \\
\hline 3 & Kabuten Tulungagung & $\begin{array}{l}\text { Berita Acara No. 170/05/040/2011: Persetujuan Bersama Badan } \\
\text { Legislasi DPRD Kab. Tulungagung dan Tim Perumus Prolegda } \\
\text { Pemda Kab. Tulungagung }\end{array}$ \\
\hline 4 & Kabupaten Lumajang & $\begin{array}{l}\text { Belum membuat Prolegda, sebab masih menyelesaikan Raperda } \\
\text { usulan Eksekutif Tahun } 2010\end{array}$ \\
\hline
\end{tabular}

Sumber: Data Sekunder Tahun 2011 diolah

Penyebab Kecenderungan Legislasi Peraturan Daerah di Jawa Timur Dilakukan Secara Elitis

\section{Prinsip Keterbukaan}

Berdasarkan paparan data fenomena legislasi Perda di lokasi penelitian dapat dikemukakan bahwa penyebab tidak dipublikasikannya Raperda dikarenakan (menurut pandangan sepihak dari SKPD maupun DPRD) adalah: (1) Raperda hanya merupakan penjabaran/derivasi/breakdown lebih lanjut dari peraturan perundangudangan yang lebih tinggi, (2) Raperda merupakan perubahan atas Perda yang sebelumnya sudah terbit, (3) jika Raperda dipublikasikan ke masyarakat maka prosesnya akan lama dan berlarut-larut sementara Pemda/DPRD sangat membutuhkan terbitnya Perda untuk menjadi dasar legal atas tindakan-tindakan publik yang akan dilakukan, (4)terbentur masalah minimnya anggaran masingmasing unit kerja (SKPD/DPRD) dalam kegiatan legislasi Perda, dan (5) tidak semua masyarakat paham materi yang diatur Raperda, sehingga Raperda tidak dipublikasikan ke masyarakat.

\section{Prinsip Partisipasi Publik}

Berdasarkan data penelitian menunjukkan bahwa paling tidak ada 5 (lima) penyebab terbatasnya pelibatan/partisipasi publik baik pada saat Raperda disusun atau sedang dibahas antara kepala daerah dengan DPRD, yaitu: 1. raperda disusun 
karena merupakan penjabaran (derivasi/breakdown) dari peraturan perundangundangan di atasnya. 2. raperda disusun sebagai perubahan atas Raperda yang sudah ada karena: (a) sudah tidak sesuai dengan perkembangan zaman dan (b) karena terbitnya aturan baru dari pemerintah pusat yang mengharuskan sebuah Raperda untuk disesuaikan dengan aturan yang baru tersebut. 3. jika masyarakat dilibatkan dalam penyusunan dan pembahasan Raperda maka penyelesaian penyusunan Raperda justru akan berlarut-larut. 4. masyarakat tidak dilibatkan untuk memberikan masukan dalam penyusunan dan pembahasan Raperda karena masalah terbatasnya anggaran. 5. karena substansi/materi dan masalah yang diatur dalam dalam Raperda tidak dipahami oleh masyarakat.

\section{Prinsip Persamaan/Kesetaraan}

Berdasarkan paparan data empirik hasil penelitian diketahui paling tidak ada 2 (dua) penyebab adanya ketidaksamaan posisi masyarakat, yang ditandai dengan adanya pemilihan-pemilihan dan pemilahan-pemilahan unsur masyarakat, dalam legislasi Perda tersebut, yaitu: 1. manakala masyarakat dilibatkan dalam penyusunan/pembahasan Raperda maka penyelesaian pembentukan Raperda justru akan berlarut-larut. 2. apabila melibatkan masyarakat dikhawatirkan dalam proses pembahasan Raperda akan melebar kemana-mana dan tidak akan fokus pada substansi dasar dari Raperda yang tengah disusun atau dibahas.

\section{Prinsip Kebebasan}

Jika dianalisis, penyebab tidak maksimalnya implementasi prinsip kebebasan, baik kebebasan untuk memperoleh dan mengkritisi Raperda, barang tentu karena seperti dalam analisis kelima di atas, adalah adanya keengganan elite daerah untuk menyebarluaskan dan memberi ruang kepada masyarakat (public sphare) untuk secara kontinu berpartisipasi di semua tahapan dalam legislasi Perda di lokasi penelitian. Padahal dalam demokrasi, prinsip keterbukaan, yang dalam hal ini ditandai dengan penyebarluasan Raperda dan public sphere, merupakan wilayah yang paling vital bagi demokrasi yang mengasumsikan bahwa setiap warga negara terlibat aktif dalam proses pengambilan keputusan menyangkut kehidupan bersama. Disebabkan adanya keengganan elite daerah dalam mempromosikan asas keterbukaan dan mengikutsertakan masyarakat secara luas inilah maka legislasi Perda di lokasi penelitian cenderung menjadi elitis. 


\section{Prinsip Kontrol Rakyat terhadap Proses Kebijakan yang Dibuat Elite}

Dari sisi civil society, penyebab lemahnya kontrol masyarakat terhadap legislasi Perda adalah adanya pandangan sebagian masyarakat yang mengacuhkan proses legislasi Perda. Sedangkan dari sisi elite daerah, paling tidak ada 4 (empat) sebab kontrol publik dalam legislasi Perda sangat lemah yakni: 1. materi Raperda secara matang sudah dibicarakan di internal Tim Eksekutif dan yang terlibat di dalamnya adalah berbagai instansi/unit/satuan kerja yang ada di daerah; 2. untuk Raperda tertentu sudah mendapat masukan yang cukup memadai dari berbagai kalangan/ unsur masyarakat (stakeholders); 3. jika dimintakan persetujuan kepada masyarakat lebih dahulu bisa jadi materi Raperda akan mentah lagi padahal Raperda akan segera diajukan ke DPRD untuk memperoleh pembahasan bersama; dan 4. Raperda sudah cukup memperoleh pembahasan bersama antara Pansus DPRD dengan Tim Eksekutif dan berbagai mitra kerja lainnya.

\section{Faktor-Faktor yang Menghambat Pelembagaan Prinsip Dasar Demokrasi dalam Legislasi Peraturan Daerah di Jawa Timur}

Dari penelusuran terhadap fakta empirik (data primer) yang diperoleh di lokasi penelitian maupun fakta normatif (data skunder) dapat diketengahkan berbagai faktor yang menghambat pelembagaan prinsip dasar demokrasi dalam legislasi Perda. Paling tidak ada 5 (lima) faktor yang menghambat pelembagaan prinsip dasar demokrasi dalam legislasi Perda di lokasi penelitian yaitu: a. faktor substansi hukum, b. faktor struktur hukum, c. faktor kultur hukum, d. faktor waktu, dan e. faktor anggaran.

\section{Faktor Substansi Hukum}

Substansi hukum dibatasi pengertiannya pada peraturan perundang-undangan (peraturan hukum) yang dibentuk oleh lembaga yang berwenang untuk menjalankan fungsi legislasi baik itu lembaga legislatif di tingkat pusat maupun di tingkat daerah dan lembaga eksekutif baik di tingkat pusat maupun di tingkat daerah. Peraturan hukum ini mulai dari yang berjenis Undang-Undang, Peraturan Pemerintah, Peraturan Presiden, Perda, Peraturan Menteri, Peraturan DPRD, maupun Keputusan DPRD.

Apabila ditelaah secara lebih mendalam akan segera tampak bahwa perumusan prinsip dasar demokrasi - yakni prinsip keterbukaan dan prinsip partisipasi publik - dalam legislasi Perda pada berbagai peraturan hukum tersebut mengerucut dalam dua kutub. Pertama, peraturan hukum yang sudah merumuskan prinsip dasar 
demokrasi namun prinsip tersebut pada dasarnya tidak dirumuskan secara imperatif. Kedua, peraturan hukum yang di dalamnya sama sekali tidak mencantum maupun merumuskan prinsip dasar demokrasi dalam legislasi Perda.

\section{Faktor Struktur Hukum}

Struktur hukum di sini diberi pengertian sebagai kelembagaan yang diciptakan oleh sistem hukum yang bersangkutan dengan berbagai macam fungsinya dalam rangka mendukung bekerjanya sistem hukum tersebut. ${ }^{13}$ Meski ada yang menyatakan bahwa lembaga legislatif merupakan lembaga politik, namun karena eksistensinya dilahirkan dari suatu produk, memiliki fungsi-fungsi dan tugas-tugas di bidang hukum, seperti fungsi pembentukan hukum perundang-undangan, maka tidak salah jika lembaga legislatif sejatinya juga merupakan salah satu komponen sruktural hukum.

Secara normatif, keberadaan lembaga legislatif di Indonesia beserta berbagai fungsi yuridisnya - yakni fungsi legislasi, fungsi anggaran, fungsi pengawasan, dan fungsi perwakilan - sudah tidak ada yang mempersalahkan. Namun implementasi fungsi-fungsi tersebut masih menjadi permasalahan tersendiri.

Banyaknya Perda yang dibatalkan oleh Menteri Dalam Negeri karena setelah dievaluasi dinyatakan bertentangan dengan kepentingan umum menunjukkan bahwa lembaga legislatif dan eksekutif tidak memperhatikan kepentingan publik. Ini artinya produk-produk hukum daerah yang dihasilkan oleh lembaga ini tidak memperhatikan dan menerapkan prinsip-prinsip dasar demokrasi ketika kedua lembaga di daerah sedang memproses pembentukan Perda.

Di lokasi penelitian, faktor struktural lainnya adalah belum terbentuknya lembaga independen di daerah di luar DPRD dan pemerintah daerah yang sebenarnya juga memiliki peran strategis dalam pelembagaan prinsip dasar demokrasi. Kota Probolinggo yang telah memiliki dua Perda yang terkait dengan demokratisasi dalam legislasi Perda, yakni Perda No. 5 Tahun 2003 tentang Partisipasi Publik dan Perda No. 6 Tahun 2003 Kebebasan Memperoleh Informasi telah mengamanatkan dibentuk Komisi Pengaduan dan Komisi Informasi.

\section{Faktor Kultur Hukum}

Yang dimaksud dengan kultur hukum adalah berupa nilai-nilai dan sikap-sikap yang merupakan pengikat sistem itu serta menentukan tempat sistem hukum itu di

${ }^{13}$ Satjipto Rahardjo, Hukum dan Masyarakat, Penerbit Angkasa, Bandung, 1984, hlm. 84 
tengah-tengah kultur hukum bangsa secara keseluruhan. Salah satu sikap rakyat Indonesia terhadap hukum atau pejabat-pejabat hukum adalah lebih cenderung kepada orientasi terhadap orang dibanding terhadap hukum itu sendiri. Petugaspetugas hukum ditaati bukan karena alasan-alasan karena kepatuhannya terhadap hukum negara. ${ }^{14}$

Berdasarkan data penelitian yang berasal dari wawancara baik dengan responden anggota DPRD maupun dari pihak eksekutif di lokasi penelitian dapat menjadi petunjuk tentang sikap mereka dalam kaitannya dengan pelembagaan prinsip dasar demokrasi dalam legislasi Perda. Jawaban responden mengarah pada dua hal yakni: 1) Ada responden yang telah mengimplementasikan dua prinsip dasar demokrasi dalam legislasi Perda. Pertimbangannya adalah agar Perda setelah diundangkan nantinya efektif maka sebelumnya harus memperoleh masukan dari masyarakat.

Secara umum dapat disimpulkan bahwa meski ada proses publikasi dan partisipasi masyarakat, namun proses ini tampaknya masih bersifat artifisial, karena hanya sekali masyarakat diajak bicara untuk memberi masukan pada saat proses penyiapan dan pembahasan Raperda. Bagaimana kemudian hasil dari masukanmasukan masyarakat apakah benar-benar akan menjadi warna perubahan Raperda pada dasarnya masyarakat tidak mengetahui. Hal ini karena elite daerah tidak lagi mempublikasikan lagi hasil serap aspirasi masyarakat tersebut dalam suatu proses uji publik lanjutan.

2) Di samping itu juga ada responden yang menyatakan bahwa jika proses partisipasi masyarakat ditempuh, maka proses pembahasan akan bertele-tele. Permintaan dan masukan masyarakat sangat beraneka ragam, sehingga dikhawatirkan tidak akan bisa fokus pada substansi Raperda. Jika diberi kesempatan maka bisa dipastikan bahwa Raperda tidak akan jadi sementara Pemda sangat membutuhkan Perda tersebut.

\section{Faktor Waktu}

Waktu yang terbatas juga menjadi faktor penyebab tidak terlembagakannya prinsip dasar demokrasi berikutnya dalam proses pembentukan Perda di lokasi

${ }^{14}$ Daniel S. Lev, "Judicial Institution and Legal Culture in Indonesia", dalam Claire Holt (ed.), Culture and Politics in Indonesia, Penerbit Cornell University Press, Ithaca, 1972, hlm. 281. 
penelitian. Memang tidak semua Raperda yang dibentuk selalu terkait dengan keterbatasan waktu untuk menyiapkan/menyusun maupun membahasnya. Beberapa Raperda ketika sedang disiapkan/disusun di tingkat SKPD maupun ketika dibahas tidak ada kendala waktu untuk menyelesaikannya.

Pada umumnya masalah keterbatasan waktu itu terjadi baik terhadap Raperda ketika sedang disusun di tingkat SKPD maupun ketika sedang dibahas bersama antara Tim SKPD dengan DPRD. Keterbatasan waktu penyiapan/penyusunan dan pembahasan Raperda tersebut disampaikan oleh semua responden di lokasi penelitian ketika menyusun dan membahas Raperda terkait dengan pungutan yang akan diterapkan kepada masyarakat.

\section{Faktor Anggaran}

Jika ditelusuri lebih lanjut alokasi anggaran legislasi Perda masih sangat minim dibanding dengan Raperda yang dibahas setiap tahunnya. Berapa anggaran legislasi Perda setiap tahunnya, ternyata masing-masing responden DPRD maupun SKPD mengaku tidak tahu persisnya. Dengan demikian dalam laporan penelitian ini tidak bisa diketengahkan besaran anggaran legislasi Perda setiap tahun anggaran untuk masing-masing.

Secara umum dapat diketengahkan bahwa meski sudah ada Prolegda yang di dalamnya direncanakan sekian jumlah Raperda yang akan dibahas dalam satu tahun anggaran, namun pos anggaran tersebut sebenarnya kurang memadai. Dalam perhitungan kasar yang dilakukan oleh responden, anggaran legislasi setiap Perda itu dialokasikan untuk: 1) pembuatan naskah akademik, 2) perancangan/perumusan draf Raperda, 3) studi banding, 4) kegiatan publikasi dan partisipasi publik, dan 5) pembahasan Raperda.

\section{Konseptualisasi Legislasi Peraturan Daerah ke Depan dalam Perspektif Demokrasi}

Agar produk hukum daerah tidak berparadigma elitisme, maka kehendak elite harus dipertemukan dan diharmonisasikan dengan kehendak umum rakyat. Idealnya dalam tahapan legislasi Perda harus dapat mempertemukan antara kehendak, kepentingan, dan kebutuhan elite dengan kehendak, kepentingan, dan kebutuhan rakyat. Inilah yang menjadi argumentasi perlunya untuk membangun suatu konsep ideal legislasi Perda masa depan yang berparadigmakan demokrasi berlandaskan harmoni kepentingan elite-rakyat. Konsep ideal legislasi Perda yang mencerminkan harmoni kepentingan elite-rakyat tersebut dapat diketengahkan 
sebagai berikut.

Pertama, elite daerah, baik yang berada di lembaga legislatif maupun di lembaga eksekutif, pada setiap tahapan legislasi Perda yang dimulai dari proses perencanaan, pembahasan, hingga pengambilan keputusan atas suatu Raperda niscaya selalu melibatkan warga masyarakat lokal. Pelibatan masyarakat dalam setiap tahapan legislasi Perda tidak sekedar dalam tataran formal-prosedural saja, namun dalam maknanya yang lebih substantif.

Kedua, pada tahap perencanaan, elite daerah harus menyusun Program Legislasi Daerah yang berisi proyeksi nama-nama Raperda pada tahun yang akan datang berdasarkan pada kebutuhan riil daerah yang bersangkutan, baik karena didasarkan pada amanat peraturan perundang-undangan di atasnya, untuk melaksanakan otonomi dan tugas pembantuan, maupun berdasarkan kebutuhan rakyat setempat. Prolegda tersebut niscaya dipublikasikan ke tengah-tengah publik agar sekalian warga masyarakat setempat mengetahui apa saja Raperda yang akan dikerjakan oleh elite daerah.

Ketiga, sebelum menyusun dan merumuskan Raperda maka segenap elite daerah harus membuat naskah akademik terlebih dahulu sebagai naskah awal yang memuat gagasan-gagasan pengaturan dan pokok-pokok materi muatan bidang tertentu sebagai bahan pertimbangan yang paling objektif dan rasional dalam penyusunan Raperda yang ditinjau dari sisi kelayakan filosofisnya, sosiologisnya, politisnya, maupun yuridisnya. Penyusunan naskah akademik ini tentunya didahului dengan serangkaian pengkajian dan penelitian terhadap keempat aspek tersebut.

Keempat, agar rumusan ketentuan dalam Raperda memenuhi syarat formal peraturan perundang-undangan, maka elite daerah harus dibantu oleh tenaga perancang Perda sebagai tenaga fungsional yang berkualitas yang khusus bertugas untuk menyiapkan, mengolah, dan merumuskan Raperda. Oleh karena itu, tenaga perancang Perda sangat diperlukan mengingat elite daerah belum tentu dapat membuat rumusan ketentuan Perda secara baik dan sistematis menurut kelaziman dalam penyusunan peraturan perundang-undangan.

Kelima, setelah penyusunan draf Raperda selesai, maka elite daerah harus menyebarluaskan draf tersebut kepada publik. Penyebarluasan draf Raperda dimaksudkan untuk memperoleh tanggapan maupun usul-saran perbaikan dari publik, sehingga kekurangan-kekurangan yang ada dapat ditambahkan dan diperbaiki, sementara hal-hal yang tidak perlu dimasukkan kemudian dihilangkan 
dari Raperda.

Keenam, saat pembahasan di lembaga legislatif, maka elite daerah harus mengundang dan melibatkan sebanyak mungkin elemen-elemen - terutama kepada stake holders (pihak yang berkepentingan dan menjadi tujuan penerbitan Perda) di luar elite daerah - yang ada di masyarakat, untuk ikut membahas dan memberi masukan dalam rangka penyempurnaan Raperda. Penggunaan terminologi "elemenelemen yang ada di masyarakat" di sini dengan pertimbangan bahwa tidaklah mungkin membuat Perda dilakukan seperti pelaksanaan Pemilu yang melibatkan semua rakyat yang memiliki hak pilih.

Ketujuh, pada saat Raperda telah mendekati akhir untuk ditetapkan menjadi Perda, maka elite daerah hendaknya melakukan "konsultasi publik"15 dan "uji publik" terlebih dahulu untuk melihat reaksi masyarakat terhadap Raperda tersebut. Setidaknya ada dua hal yang ingin dicapai dari kegiatan tersebut, yaitu: (1) untuk mengetahui respons masyarakat terhadap Raperda yang akan ditetapkan, dan (2) untuk memperoleh persetujuan publik terhadap Raperda yang akan ditetapkan. Dalam konteks ini, elite daerah harus memiliki orientasi etis "hikmahkebijaksanaan"16 untuk mengagregasikan kepentingan rakyat.

Kedelapan, Perda yang sudah diundangkan dalam lembaran daerah jika dirasa oleh rakyat di dalamnya ada materi yang bertentangan dengan peraturan perundangundangan yang lebih tinggi serta bertentangan dengan kepentingan umum dan keadilan masyarakat, maka rakyat harus diperkenankan untuk melakukan judicial review ke Mahkamah Agung. Adalah tidak tepat jika proses assesment terhadap Perda dilakukan oleh Gubernur ataupun Mendagri, sebab hasil dari proses legislasi bukan merupakan beschikking namun merupakan regelling sehingga pengujiannya harus ke Mahkamah Agung.

Demikian pokok-pokok gagasan konsep ideal tentang demokrasi dalam kaitannya dengan legislasi Perda yang berlandaskan harmoni kepentingan eliterakyat. Dari konsepsi-konsepsi ideal yang dikemukakan tersebut tampak sudah bahwa demokrasi yang berparadigmakan harmoni elite-rakyat dalam pembentukan Perda niscaya bersifat top-down dan sekaligus buttom-up secara timbal balik dan berkelanjutan untuk mencapai titik temu berbagai kepentingan dan aspirasi sehingga

\footnotetext{
${ }^{15}$ Sadu Wasistiono dan Yonatan Wiyoso, Meningkatkean Kinerja Dewan Perwakilan Rakyat Daerah (DPRDI, Penerbit Fokusmedia, Bandung, 2009, hlm. 189.

${ }^{16}$ Yudi Latif, Negara Paripurna, Historisitas, Rasionalitas, dan Aktualitas Pancasila, PT Gramedia Pustaka Utama, Jakarta, 2011, hlm. 487.
} 
dapat dihasilkan produk Perda yang secara maksimal memuaskan sebanyak mungkin pihak yang akan terkena dampak implementasi Perda.

\section{Penutup}

Pertama, penyebab legislasi Perda yang cenderung elitis adalah: adanya keengganan elite daerah untuk menyebarluaskan dan memberi ruang kepada masyarakat untuk secara kontinyu berpartisipasi dalam legislasi Perda, Raperda hanya merupakan breakdown dari peraturan perundang-undangan di atasnya, Raperda merupakan perubahan atas Perda yang sebelumnya sudah terbit, prosesnya akan lama dan berlarut-larut, pembahasan Raperda tidak fokus, minimnya anggaran dalam kegiatan legislasi Perda, tidak semua masyarakat paham materi yang diatur Raperda, sebagian masyarakat mengacuhkan legislasi Perda, dan elite daerah menganggap bahwa Raperda sudah memperoleh pembahasan secara seksama antara DPRD dan Pemerintah Daerah.

Kedua, berbagai faktor yang menghambat pelembagaan prinsip dasar demokrasi dalam legislasi Perda di lokasi penelitian adalah: a. faktor substansi hukum, b. faktor struktur hukum, c. faktor kultur hukum, d. faktor terbatasnya waktu, dan e. faktor minimnya anggaran legislasi Perda.

Ketiga, berdasarkan hasil eksplorasi terhadap berbagai gagasan yang ada dan informasi yang diperoleh dari data di lokasi penelitian, maka konsep ideal legislasi Perda ke depan menurut perspektif demokrasi adalah berparadigma harmoni eliterakyat. Gagasan dasar legislasi Perda menurut perspektif demokrasi yang berparadigma harmoni elite-rakyat adalah menempatkan elite politik dan rakyat dalam posisi yang sama pentingnya. Oleh karenanya, interaksi politik demokratis dalam pembentukan Perda ini niscaya bersifat top-down dan sekaligus buttom-up secara timbal balik dan berkelanjutan untuk mencapai titik temu berbagai kepentingan dan aspirasi sehingga dapat dihasilkan produk Perda yang secara maksimal memuaskan sebanyak mungkin pihak yang akan terkena dampak implementasi Perda. Kerangka konsep ideal legislasi Perda yang berdasarkan pada perspektif demokrasi dengan berparadigma harmoni elite-rakyat tersebut adalah: (a) elite daerah pada saat melalukan proses penyusunan Perda niscaya selalu melibatkan warga masyarakat lokal; (b) pada tahap perencanaan, elite daerah harus membuat Prolegda terlebih dahulu; (c) sebelum merumuskan draf Raperda, maka 
elite daerah harus menyusun naskah akademik terlebih dahulu; (d) elite daerah harus dibantu oleh tenaga perancang Perda; (e) elite daerah harus menyebarluaskan setiap draf Raperda kepada publik; (f) pada saat pembahasan, maka elite daerah harus mengundang dan melibatkan sebanyak mungkin elemen masyarakat; (g) sebelum disetujui dan ditetapkan menjadi Perda, elite daerah hendaknya melakukan konsultasi publik dan uji publik; (h) rakyat diberi kesempatan untuk melakukan judicial review ke Mahkamah Agung, dan bukannya Gubernur maupun Mendagri.

Berdasarkan simpulan di atas, maka untuk memperbaiki proses pembentukan Perda agar tidak cenderung elitis maka patut disarankan sebagai berikut: Pertama, agar para elite daerah bersedia menerapkan secara seksama prinsip dasar demokrasi yakni openness principle dalam segala tingkatan legislasi Perda mulai dari perencanaan hingga sampai dengan penetapan Raperda. Kedua, agar dibuat pos anggaran khusus untuk publikasi Raperda dan partisipasi masyarakat dalam penyusunan dan pembahasan Rperda dalam anggaran legislasi Perda baik dalam anggaran Pemerintah Daerah maupun dalam anggaran DPRD. Ketiga, berbagai peraturan perundang-undang baik yang ada pusat maupun yang ada di daerah yakni Peraturan Tatib DPRD di masing-masing lokasi penelitian niscaya diamandemen dengan memasukkan prinsip-prinsip dasar demokrasi. Keempat, harus ada perubahan pandangan elite daerah terhadap posisi mereka sebagai wakil rakyat yang seharusnya senantiasa dekat dengan rakyat sehingga dalam legislasi Perda selalu mengikutsertakan rakyat. Kelima, untuk menguatkan pengetahuan masyarakat tentang hak-hak mereka dalam demokratisasi legislasi Perda, maka masyarakat harus diadvokasi dan didorong untuk selalu mengawasi proses legislasi Perda di daerahnya masing-masing.

\section{Daftar Pustaka}

Adji Samekto, F.X., Studi Hukum Kritis, Kritik Terhadap Hukum Modern, Badan Penerbit Universitas Diponegoro, Semarang, 2003.

Akkersmans, P.W.C., et al., Algemene Begrippen van Staatsrecht, deel I, W.E.J. Tjeenk, Zwolle, 1985.

Bühlmann, Marc, Wolfgang Merkel, and Bernhard Wessels, The Quality of Democracy: Democracy Barometer for Established Democracies. NCCR Democracy, University of Zurich, Social Science Research Centre Berlin (WZB) , 2007. 
Burkens, M.C., et al., Beginselen van de Democratische Rechtsstaat, W.E.J. Tjeenk Willink, Zwolle in Samenwerking met het Nederlands Institut voor Sociaal en Economisch Recht, NISER, 1990.

“Baru 973 Perda Bermasalah yang Dibatalkan”, Kompas, 16 Juli 2008.

Campbell, Tom and Adrienne Stone (Ed.), Law and Democracy, Dartmouth Publishing Company-Ashgate Publishing Limited, Burlington, 2003.

De Haan, P., et al., Bertuursrecht in Sociale Rechtsstaat, deel 2 Bertuurshandelingen en waarborgen, Kluwer, Deventer, 1986.

Dworkin, Ronald, "The Moral Reading”, dalam Tom Campbell and Adrienne Stone (Ed.), Law and Democracy, Dartmouth Publishing Company-Ashgate Publishing Limited, Burlington, 2003.

Endi Jaweng, Robert, “Ihwal Perda Bermasalah”, Kompas, 24 Maret 2006.

Ferejohn John, Participation and Democracy, Stanford University, 2005.

Isra, Saldi, "Agenda Pembaruan Hukum: Catatan Fungsi Legislasi DPR”, Jentera Jurnal Hukum, Edisi 3-Tahun II, November 2004.

J. Chambliss, William dan Robert B. Seidman, Law, Order and Power, Addison-Wesley Publishing, Inc. Philippines, 1971.

Kasim, Ifdhal, "Mempertimbangkan 'Critical Legal Studies' dalam Kajian Hukum di Indonesia”, Jurnal Wacana, Edisi 6, Tahun II, 2000.

Latif, Yudi, Negara Paripurna, Historisitas, Rasionalitas, dan Aktualitas Pancasila, PT Gramedia Pustaka Utama, Jakarta, 2011.

L. Binawan, Al. Andang, "Merunut Logika Legislasi”, Jentera Jurnal Hukum, Edisi 10 - Tahun III, Oktober 2005.

M. Hadjon, Philipus, "Keterbukaan Pemerintahan dan Tanggung Gugat Pemerintah", makalah pada Seminar Hukum Nasional Reformasi Hukum Мепuјu Terwujudnya

Masyarakat Madani (Civil Society), Badan Pembinaan Hukum Nasional, Departemen Kehakiman, Jakarta, 12-15 Oktober 1999.

Rahman Alamsyah, Andi, "Membangun Oposisi, Memperluas Akuntabiltas, dan Memperkuat Kapasitas: Menuju Pengawasan DPR yang Efektif", Jentera Jurnal Hukum, Edisi 20 - Tahun V, Januari-April 2010

Rahardjo, Satjipto, Hukum dan Masyarakat, Angkasa, Bandung, 1984.

Sosiologi Hukum, Perkembangan, Metode, dan Pilihan Masalah, Penyunting Khudzaifah Dimyati, Muhammadiyah University Press, Surakarta, 2002.

S. Lev, Daniel, “Judicial Institution and Legal Culture in Indonesia” dalam Claire Holt (ed.), Culture and Politics in Indonesia, Penerbit Cornell University Press, Ithaca, 1972.

Vago, Steven, Law and Society, Prentice Hall, Upper Saddle River, New Jersey, 1997. 
Varma, SP., Teori Politik Modern, terjemahan dari Modern Political Theory, Alih Bahasa, Yohanes Kristiarto SL (dkk.), PT RajaGrafindo Persada, Jakarta, 2007.

Wasistiono, Sadu dan Yonatan Wiyoso, Meningkatkan Kinerja Dewan Perwakilan Rakyat Daerah (DPRDI, Penerbit Fokusmedia, Bandung, 2009. 